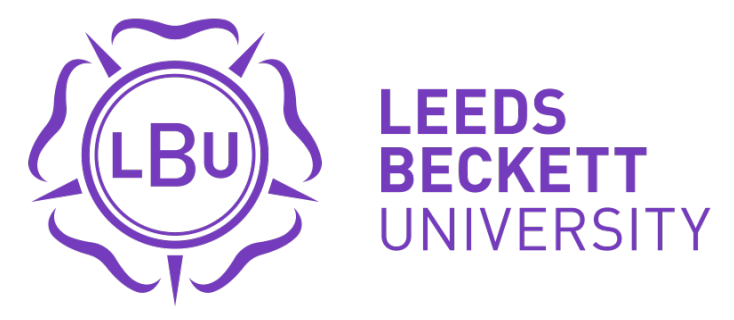

Citation:

Dunn, PJ and Oyegoke, AS and Ajayi, S and Palliyaguru, R and Devkar, G (2021) Challenges and benefits of LED retrofit projects: a case of SALIX financed secondary school in the UK. Journal of Engineering, Design and Technology. ISSN 1726-0531 DOI: https://doi.org/10.1108/jedt-08-20210424

Link to Leeds Beckett Repository record:

https://eprints.leedsbeckett.ac.uk/id/eprint/8152/

Document Version:

Article (Accepted Version)

Creative Commons: Attribution-Noncommercial 4.0

The aim of the Leeds Beckett Repository is to provide open access to our research, as required by funder policies and permitted by publishers and copyright law.

The Leeds Beckett repository holds a wide range of publications, each of which has been checked for copyright and the relevant embargo period has been applied by the Research Services team.

We operate on a standard take-down policy. If you are the author or publisher of an output and you would like it removed from the repository, please contact us and we will investigate on a case-by-case basis.

Each thesis in the repository has been cleared where necessary by the author for third party copyright. If you would like a thesis to be removed from the repository or believe there is an issue with copyright, please contact us on openaccess@leedsbeckett.ac.uk and we will investigate on a case-by-case basis. 


\section{Challenges and benefits of LED retrofit projects: A case of SALIX financed secondary school in the UK}

Paul James Dunn, Adekunle Sabitu Oyegoke, Saheed Ajayi, Roshani Palliyaguru and Ganesh Devkar

Purpose: The recent surge in light emitting diode (LED) lighting retrofitted into schools in the UK is as a result of the UK Government's 2050 zero carbon pledge. However, the benefits and consequences of LED retrofit projects for staff and enablers, and stakeholder knowledge gaps about LED lighting retrofitting have not been fully explored. The aim of this research is to determine the amount of savings in cost, carbon reduction, and kilowatt usage and to confirm if repayment from energy and cost savings derived from LED retrofit school projects funded through the SALIX funding option in the UK would be enough to service the loan. Thus, it examines monetary and non-monetary benefits, internal project stakeholder knowledge gaps, and the consequences of LED retrofit for the staff and enablers of a large community college in the UK which is funded through the SALIX funding option.

Design/methodology/approach: The methodology relied on a hybrid research approach of a case secondary school through the review of literature, analysis of secondary data, focus group and questionnaire survey. The focus group consists of six key project stakeholders. The secondary data was sourced from the Project IGP [Individual Grade Proposal] and the Positive Energy Report from Zenergi, and the closed online questionnaire survey was used to sample 150 teaching staff and school enablers.

Findings: The findings show that stakeholders lack project knowledge, trust, and expertise/project comprehension. This is in terms of baseline information, LED technology/management, payback modalities, management of risks and ethical issues around environmental impact. The forecasted SALIX savings were not achieved in real-time, partly because it does not take into consideration the increase in energy costs over the payback period. However, the LED retrofit creates efficiencies; drives down energy costs and energy usage; and drives carbon reduction, helping pupils' learning, improving productivity and performance, and finally leading to a better lighting environment for the school community.

Originality: The study will help schools in the UK that intend to access SALIX finance for LED retrofits to understand the challenges and mitigate the risks. It will also help the government to understand the importance of adjusting the payback modalities to the base price when the 
retrofit was carried out for real-time savings to be made. The research would be useful in ensuring the proactive involvement of all the identified stakeholders in understanding the challenges and what the function entails.

Keywords: LED retrofit, stakeholder's benefits, SALIX financed scheme, secondary school, UK

\section{INTRODUCTION}

The Facilities Management (FM) profession has a wide range of disciplines, with environmental control and sustainability at the forefront of organisational strategy (Alexander, 2016). One aspect of environmental control is LED lighting, which has been around for some 30 years. Recently, LED technology has taken the lead in providing high efficacy, longer lifecycles and contributing to the prevention of global warming. LED lighting offers safety benefits via a oneway electrical current, demanding less power and heat. It also offers reliability and is considered less harmful to the environment (Lenk and Lenk, 2011).

More recently, the UK government has written into law a reduction in emissions, promising to be the first carbon "Zero" economy by 2050 (The Department for Business, Energy and Industrial Strategy, 2019). Organisations are now legally obliged to reduce carbon emissions, thus, polarising facility managers into a new era of project design to support the core business. Chinchero et al., (2020) identified buildings as major consumers of global energy. Lighting within the built environment contributes significantly to global warming. The Climate Group (2020) states that $6 \%$ of the planet's carbon emissions are through lighting, as buildings are "thermodynamic engines" (Braham and Willis, 2013). Appleby (2013) suggests that 'retrofitting' of existing buildings with energy-efficient infrastructure delivers carbon reductions, potentially solving carbon usage issues in older buildings. LED lighting innovation presents "greater lighting efficacies, from around $10 \mathrm{~lm} / \mathrm{W}$ in 1995, to around $90 \mathrm{~lm} / \mathrm{W}$ in 2011" (Stravoravdis, 2013).

The continuous surge in the global LED Retrofit market size is another indication of increasing usage. According to Marketwatch (2021), the global LED Retrofit market size is projected to reach 
USD 5782.9 million by the end of 2027, from USD 4170.2 million in 2020, growing at a Cumulative Annual Growth Rate (CAGR) of 5.6\% during 2022-2027. In the UK alone, The Interactive Biodiversity Information Systems Limited (2020) market research data shows that the LED industry is worth $\mathrm{f3}$ billion to the economy. This forecast is set to grow, as LED promises up to a $45 \%$ saving on the organisation's energy bill (Pye, 2020). The UK Energy Watch (2020) suggests that schools can save ' 620 ' thousand tonnes of Co2 entering the atmosphere. The Department for Education (2020) confirms that academies have a major responsibility for reducing carbon through energy saving initiatives. Therefore, the Department for Energy and Climate Change (2019) issued guidance titled "financing energy efficiency in the public sector" to promote LED retrofit. The government is providing funding through the Department for Business, Energy and Industrial Strategy [DBEIS] through the Department for Education for schools and colleges to reduce energy costs through the installation of energy efficiency technologies under the SALIX Energy Efficiency Loan Scheme (SEELS) (SALIX, 2020). LED lighting is one of the approved technologies to reduce school energy bills and improve the learning environment for both staff and pupils (SALIX, 2020). Under these 'attractive' circumstances, it is not surprising that schools are seeking improvements. LED lighting promises better learning outcomes and school environmental improvement.

SALIX Finance Limited is a non-governmental body funded by the Department of Business and Industrial Strategy and the Department of Education. The aim of SALIX is to provide funding to the public sector to reduce its overall carbon emissions and lower energy usage. As of March 2020 , SALIX has delivered $£ 971$ million of projects, with financial savings of $£ 203$ million. 867,864 tonnes of carbon were saved within the SALIX schemes supporting the public sector (SALIX, 2021). As part of the process, applicants for SALIX will need to submit savings calculations, internal business case paperwork, and evidence of the cost basis for their projects, and for larger projects, they may also need to submit a full business case to support the application (SALIX 2021).

The success of energy retrofit (ER) projects is highly dependent on the involvement of the right stakeholders at the right stage (Fasna and Gunatilake 2020). Badi's (2017) identified stakeholder knowledge gap is a huge problem in LED retrofit. Fasna and Gunatilake (2020) identified nine key 
stakeholders along with their functions and four main reflective roles in energy retrofits in the hotel sector at different stages of the decision-making process. Dandan and Humphries (2016) suggest that LED lighting is on course to be the main source of lighting within the built environment, delivering "continuous advances in efficiency and reductions in cost". The advances in technology actually deliver a cost reduction through energy savings, as presented by Pye (2020). Badi (2017) suggests an 'expertise deficiency' exists among school stakeholders. For example, the project inception briefs are short, and lack detail, subsequently resulting in a lack of stakeholder knowledge (Badi, 2017). Oyegoke (2005) emphasises on the difficulties of infrastructure finance and Badi (2017) suggests that capital is very limited within state schools, thus, making finance very attractive. There are numerous studies on LED lighting performance, but the impact of SALIX financed LED retrofit on the stakeholders, the wider benefits and actual savings has not been explored. Therefore, the aim of the paper is to determine the amount of savings in cost, carbon reduction, and kilowatt usage, and the consequences of the LED retrofit for the staff and enablers. The benefits, monetary/non-monetary values, and stakeholder knowledge gaps of LED lighting "retrofitted" into a large Community College in the UK under the SALIX scheme are examined. The selected community college has a General Annual Grant [GAG] of $f 5 \mathrm{~m}$ and a project capital investment of $£ 96.9 \mathrm{k}$.

There are a few limitations of this study. The focus of the study helped in providing suggestions and areas of improvement specific to a SALIX funded retrofit project of a large Community College in the UK. However, the use of a single case study is one of the limitations of the study. Multiple LED retrofit case studies compared with other recent 'live' cases could have supported more generalisation. Nevertheless, a more rigorous validation of the chosen single case study has been provided in the paper to derive meaningful conclusions. The study is limited to the UK because of the scheme involved, however, the same design methodology can be used to assess the benefits of local retrofit schemes.

The objectives are:

a) To gather stakeholder comprehension (knowledge gaps) of the LED retrofit process from project inception to completion and after use. 
b) To examine whether LED lighting delivers efficiency and value for the project investment.

c) To measure the consequences for the staff and enablers after the LED lighting retrofit project.

\section{LITRATURE REVIEW}

A lot of research studies have been carried out under the sustainable energy efficiency drive, covering different aspects, including technologies for energy efficiency (Dadzie, et al. 2020), tidal energy physics on turbine blade design for renewable clean energy sources to generate electricity and less $\mathrm{CO} 2$ emissions (Kulkarni 2018) and the effects of variation in room surface reflectance, looking holistically at the combinations on user perception, mean room surface exitance (MRSE), average horizontal illuminance and overall uniformity of horizontal illuminance (Roy 2021). The construction industry is continuously driving LED technological advancements, thus, presenting business opportunities. This business momentum is also driven by the government's carbon reduction mission within the public sector (The Department for Business, Energy and Industrial Strategy, 2019). Josijević (2017) suggests that poorly manufactured LED assets will directly impact on any organisational perceptions of saving. This is seen as a maintenance burden, often misunderstood by project stakeholders and the end users. Divine (2016) suggests that excess heat generated by LED lighting is contributing to the slow failure of LED illuminance. Dandan and Humphries (2016) provide a counter argument, stating LED illumines have an average of 15,000 hours of life [some up to 20,000 hours].

\section{Stakeholder comprehension of the process and issues related to LED performance}

For stakeholders to deliver value, Lawson et al (2021) postulate that it has to be supported by functional governance, which is critical for effective value creation practice in asset integrity and improvement project portfolios. In addition, early engagement of the key stakeholders with clearly defined roles and the utilisation of project value management artifacts, enables effective value delivery throughout the project lifecycle (Lawson et al 2021). Wilson and Rezguis's (2013) work on stakeholder perceptions within sustainability construction projects covered 23 diverse 
groups of stakeholders. Their findings indicate that all the parties to the project had a perception of a 'moral responsibility' to protect the environment. The moral responsibility is also driven by the recent guide to financing energy efficiency in the public sector (DECC, 2015). The aim of the guide is to support aspirations for carbon reductions, thus, gaining an understanding of how to deliver better energy efficiencies. The guide presents key statistics and advice on the benefits of delivering sustainability projects, however, the guide mentions a "requirement for external advisors". This is the only advisory mention of any support, going on to remind organisations of their lawful responsibilities (DECC, 2015).

Wilson and Rezguis's (2013) study also concluded that knowledge of best practice was deficient in many project areas. Their research demonstrated that stakeholders had a deep distrust of specialist information. In many cases, contractors presented contrasting data to stakeholders to gain the "commercial edge" (Wilson and Resgui 2013). Carrillo et al (2008) questioned a large number of customers involved in financing construction projects. Their results revealed a barrier of expertise amongst stakeholders, most especially. One-off scheme generally had low levels of experience within the stakeholder cohort over more regular project outcomes. The concept of "naiveness of customers" was explored by (Higgins and Jessop 1965) and Badi (2017) suggests a lack of trust towards contractors who deliver public sector sustainability projects as a problem for stakeholders.

\section{Cost Benefit of LED}

According to Pye (2020), monetary savings for the organisation can be as much as $45 \%$ when considering LED lighting. This was challenged by Raditschova and Gasparovsky (2018) by critically evaluating LED lighting technology with clear cost benefits of the LED retrofit. They came to the conclusion that stakeholders should be cautious about the LED's long-term lifecycle. LED assets typically fail faster than fluorescent illumination, thus delivering long-term cost implications. Bento and Marques (2020) postulate that the lifespan of LED technology is a major financial and maintenance hurdle for an organisation. In another study, Kaip (2017) identified a number of drawbacks through a case study of a university LED retrofit project. The drawbacks include longer 
payback times for LED lighting, with installation costs and LED maintenance being contributors to unaffordability, thus presenting future budgeting constraints and leaving the open question of whether LED lighting delivers any long-term tangible future value (Kaip 2017). However, Kaip's (2017) study is characterised by a major deficiency since it fails to account for every building within the campus under research, thus, potentially being tangibly inaccurate.

The latest Energy Technology List [ETL] issued by the Department for Business and Industrial Strategy [DBIS] (2020) is designed to keep organisations up to speed with the latest lighting technology. This document contradicts the arguments posed by Raditschova and Gasparovsky (2018), Bento and Marques (2020) and Kaip (2017). DBIS (2020) clearly defines LEDs as the "highest efficacy and lamp life of all that are cost-effective to run and are easy to control and maintain". Kaip (2017) also demonstrates a 3.8 metric tonne saving in overall carbon by switching some buildings within Miami University to LED lighting. Mills and Jacobson (2013), Dupuis (2014) also present data arguing that LED lighting delivers significant environmental benefits. For example, as LED lighting lacks mercury, it makes recycling and disposal safer (Mills and Jacobson, 2013). Thus, it positively impacts on the organisations' environmental mission. LED lighting, therefore, can be said to present both tangible and intangible long-term gains.

\section{End User, Non-monetary benefits of LED}

Research by Rongpeng et al., (2020) discovered that LED lighting resulted in employees' poor sleep quality, observing the impacts on work effectiveness of office staff that were exposed to dynamic lighting (Rongpeng et al., 2020). It is well known that children's eyes are more sensitive to variable lighting conditions, potentially hindering academic performance (Dunn et al., 1985). The field research undertaken by Gentile, et al (2017), explores the lighting conditions within secondary education. Gentile, et al (2017) found no evidence that LED lighting had a negative effect on pupil learning. However, it was noted in the research that LEDs had a $78 \%$ energy efficiency saving over the similar fluorescent luminaries fitted in classrooms. Clinical research by Batra (2017) discovered that LED lighting prone to flickering resulted in optical health issues. Batra (2017) concluded that flickering LEDs cause eyestrain, fatigue and headaches. Flickering 
within a retrofit project is possible due to the overlay of installations. For example, new lighting often uses older retro controls. Table 1 presents key stakeholders' themes, a brief description and reference sources from the literature review. It includes comprehension of benefits, increment in cost, trust issues, reliance on others, end user's negative perception, lifecycle and reduction in maintenance burden, and lack of experience.

Table 1 identification of key retrofit issues from the literature review

\begin{tabular}{|c|c|c|}
\hline Category or theme & Brief description & Evidence from data / reference to paper \\
\hline $\begin{array}{l}\text { Carbon Reduction } \\
\text { (CR) }\end{array}$ & Aspiration of (CR) & $\begin{array}{l}\text { Meeting the legislation: A guide to financing energy } \\
\text { efficiency in the public sector } 2015 \text { (c.9-14) } \\
\text { London: DECC. }\end{array}$ \\
\hline Tangible (TA) & Aspiration of (TA) benefits & $\begin{array}{l}\text { Monetary savings: The comprehension of LED } \\
\text { Savings Pye (2020) }\end{array}$ \\
\hline Intangible (INT) & Aspiration of (INT) benefits & $\begin{array}{l}\text { Non-Monetary value/benefit: LED improved } \\
\text { learning for pupils (Gentile., et al 2017) }\end{array}$ \\
\hline $\begin{array}{l}\text { Lack of Experience } \\
\text { (LOE) }\end{array}$ & $\begin{array}{l}\text { Lack of LED project experience } \\
\text { (LOE) }\end{array}$ & $\begin{array}{l}\text { Naive customer. Badi (2017) Higgins and Jessop } \\
\text { (1965) }\end{array}$ \\
\hline Increased cost (IC) & $\begin{array}{l}\text { Awareness of LED increasing } \\
\text { cost (IC) }\end{array}$ & $\begin{array}{l}\text { Consequence of project: Raditschova and } \\
\text { Gasparovsky (2018) }\end{array}$ \\
\hline Lifecycle (LC) & Awareness of LED lifecycle (LC) & Consequence of project: Kaip (2017) \\
\hline $\begin{array}{l}\text { Reduce Maintenance } \\
\text { Burden (RMB) }\end{array}$ & $\begin{array}{l}\text { Reduction to school } \\
\text { Maintenance Burden (RMB) }\end{array}$ & Reduction consequence: Kaip (2017) \\
\hline $\begin{array}{l}\text { End user Negative } \\
\text { (EUN) }\end{array}$ & $\begin{array}{l}\text { Negative comment about LEDs } \\
\text { (EUN) }\end{array}$ & End user satisfaction: Rongpeng et al., (2020) \\
\hline Trust (TRU) & $\begin{array}{l}\text { Lack of trust to the contractor } \\
\text { (TRU) }\end{array}$ & $\begin{array}{l}\text { Contractors Promise: Badi (2017) Higgins and } \\
\text { Jessop (1965) }\end{array}$ \\
\hline Rely on others (ROO) & $\begin{array}{l}\text { Reliance on expertise of } \\
\text { outsiders (ROO) }\end{array}$ & $\begin{array}{l}\text { Seek and trust advice: New finding (Trusting } \\
\text { experts) }\end{array}$ \\
\hline
\end{tabular}




\section{RESEARCH METHODOLOGY}

A hybrid research methodology approach was used on a recently completed LED retrofit school in the UK. It includes a comprehensive review of literature, a focus group, a questionnaire survey and quantitative analysis of secondary data. The case secondary school in the UK is a successful free secondary school with over 1100 pupils and 250 teaching and support staff. The campus is spread over 9 retro buildings, including a community sports centre. The school also caters for adult learning. The school commissioned the project for completion in the summer (school holiday closure) of 2018. The project deadline was eight weeks. However, full completion was expected within 6 months in order to gain user feedback and a period of defect reconciliation.

The school applied for and was granted a SALIX government loan of $£ 96.9 k$ in 2018 to retrofit the campus with 1406 LED lights, replacing the existing fluorescent luminaries. The terms and conditions of the loan are interest fee, with a payback of $12.1 \mathrm{k}$ per annum for 8 years. However, the school must deliver the payback through savings on energy bills; but, if this is unachievable, the school will have to pay the loan back through the general annual grant [GAG]. This is significant, as the GAG funds the whole school's operations, and a payback through the GAG potentially diverts precious capital.

\section{Focus group}

Hennink (2013) states that "the purpose of a focus group is to gather perspectives". The focus group consists of six key project stakeholders that were recently involved in the LED retrofit project at the case secondary school. The aim is to gain the thoughts and aspirations of the commissioning team at the project planning phase and the actual outcomes after project completion. This will also show the impact of a client's naivety versus supplication on project outcomes. Higgins and Jessop (1965) suggest a clear differentiation between the 'naïve' and the 'sophisticated' construction customer to reveal differences in the outcomes of project drivers, like environmental ethics, finance, and end-user benefits. Group homogeneity has been considered during the research design phase to focus on the strategic level of decision making. The focus group consists of 6 members in senior leadership positions and chartered in their 
various fields. (1) A Chief Executive Officer with over 22 years' of experience (2) A principal accountant with 25 years of experience (3) a director of operations with 22 years of experience (4) a deputy principal with 20 years of experience, (5) The Head of school with 15 years of experience, and (6) a chartered surveyor with 25 years of experience. This hierarchy sample has specifically been selected to avoid any "victims" of the discussion (Woźniak, 2014). This enables a free-flowing discussion, with a rich flow of data from the six 'senior' project stakeholders. This group discussion followed pre-planned questions. This method of gathering data is considered rich in value, however, it can often be let down by poor analysis (Carey and Asbury, 2012).

An inductive analytical approach was used based on thematic analysis in analysing the results of the focus group. The process began with the identification of themes, followed by pattern recognition where emerging themes become categories, coding and encoding to develop patterns. It involved an iterative and reflexive analytical process by revisiting the data and connecting the insights to make new connections and develop complex formulations (Saldana, 2013). This method codes the data for theme identification, thus enabling categorisation (Lofland and Lofland, 1995). As demonstrated by Adu (2016), simplifying coding allows targeted synthesis for theorising and delivery of the findings. A "step up strategy" built on the model by (Saldana, 2013) was used to deliver the focus group findings and further discussion.

\section{Secondary data harvest}

Data from the Project IGP [Individual Grade Proposal] that was prepared in 2018 containing project planning data and the Positive Energy Report (Zenergi, 2020) was used to carry out pre and post LED retrofit energy performance analysis.

The IGP project plan includes:

- Proposed wattage usage of existing and new LED fittings, enabling asset performance analysis of financial investment data.

- Tangible savings on energy bills (post retrofit). 
The Positive Energy Report (Zenergi, 2020) contains:

- $\quad$ Real kWh data pre and post LED retrofit.

- Validated electricity cost information, which is monitored through paid invoices via the meters.

- Actual Co2 T data, including estimated carbon reductions (SALIX, 2017).

The sample documents selected have undergone a validity audit, designed to give credibility to the data. The validity audit examined LED fittings to establish unit price, efficiency and customerbased reviews from users and fitters. The following audit criteria were used to support LED unit selection.

- Lumens versus Watt - establish the best lumen.

- Power at load.

- $\quad$ CRI (Colour Rendering Index) "The ability of a light source to accurately render the natural colour of an object" (Ahn et al., 2019)

- $\quad$ Colour temperature versus the accommodation setting, for example, classrooms.

- Heat sink to optimise long durations of operation.

- $\quad$ Life cycle.

The secondary data enabled quantification of the effectiveness of LED lighting, thus, potentially revealing issues surrounding the consistency of performance of LEDs retrofitted into the workplaces and classrooms of a large, bustling community college.

\section{Questionnaire Survey}

To understand the intangible benefits of LED lighting, a closed online questionnaire survey was used to sample 150 end-user teaching staff and school enablers. Of these, 116 responded (77\%) and 34 failed to respond (23\%). The questionnaire focuses on the benefits, impacts, comfort, and burdens arising from the project. The impact questions include those concerning the carbon footprint, the environment, and the reduction of electricity costs. Better classrooms, group presentations when 
using a projector, the general working environment, and visual learning for pupils are under consideration as benefits questions. The comfort questions include optical comfort when using a computer screen and the implication for personal comfort in terms of sickness/headache, poor night's sleep after work, changes in stress levels, and general mood within the workplace. The burden of changing bulbs and overall maintenance of the project are also measured. The opinions were gathered via the school's Google online platform. Descriptive statistics is used to measures central tendency of a mean average, using a five-point Likert scale. This method is most suited, as it provides analysis of the end users' attitudes (McLeod, 2013). The non-tangible (end-user) benefits are important in modern day facilities management to "improve the quality of life of people and the productivity of the core business" (IWFM, 2020).

\section{DISCUSSIONS OF THE RESULTS}

Stakeholder comprehension of the process

The leading theme from the focus group was a lack of experience (LOE) in sustainability projects, which has a coding frequency tally of 23 as shown in Table 2. Lack of experience (LOE) is the No 1 for 4 of the 6 participants. This supports the Higgins and Jessop (1965) study that found construction customers are "Naive" in their approach. The DoO, who is a senior Facility Manager, and CS only responded to LOE on four occasions, understandably because they are construction professionals of many years, yet experience in this nature of project was a problem (Table 2). Notably, the LOE responses were from participants with background experience in teaching and school leadership.

The key main areas of knowledge deficiencies that were identified by the participants are:

- Project scale/financial costs - the CEO said, "SALIX projects of this scale can be quite daunting, particularly in regard to the financial costs".

- HoS: “...ours was a different experience, as I and our Local Governing Body did not want the full Local Authority led project. The consequence is that we have to pay a service level 
agreement to the LA currently for the loan, and energy. A presentation on this is provided once a year, and it is so detailed that it is lost on me. There are lights not working, and whilst there are benefits, in my experience, the project has been a nightmare".

- Commercialisation of the scheme - the CS said, "to provide a return over 20 years ...as people are sceptical of energy schemes as they are not confident in the payback".

- Baseline information - the DoF said "we do not have baselines for our carbon users. It is therefore quite difficult and time-consuming to calculate".

- Lack of understanding of LED technology/management of the lights

- Management of risk - the CS said, "The schemes are seen as historically risky, for both financial and technical reasons". The CEO also said it was risky and difficult to understand "pay back and ethical issues around environmental impact." And the DoO had issues around environmental policy."

To mitigate some of these problems, a diverse number of experts were used, along with the outsourcing of a consultant for professional advice. One of the contributors said, "we have expertise to draw on, e.g. DoF and DoO, plus head teachers contribute to the required academic knowledge base. CS provides project management and technical support in order to reduce risks through delegation. Collectively, a team was built to deliver the project. It is also important to measure baseline information before embarking on the project.

The tally frequency result in Table 2 also showed that the intangible LED benefits were a major conceptual factor when stakeholders comprehended the birth of an LED project, coming in at No 2. All the participants acknowledged the importance of the scheme. The CEO said, "it will create efficiencies and drive down energy costs. DoO adds that it will "improve productivity and performance, leading to a better lighting environment." HoS, concludes that it will "help pupil learning as staff felt that the lighting was more of a natural light".

A lack of trust in expert advice was presented as the No 3 most frequent issue. SP felt left alone after the completion of the project. DoO thinks "when you are not an expert in the field, and you have to rely on someone else to advise you, what is often delivered are projects that are the 
cheapest but poorly installed. As it is not your area of expertise, you would not know how to question this. Lack of trust can be mitigated by conducting a review process during and after project completion. Professional expertise is required to "build a level of trust and have an expert to find and explain the answers". This will also, according to one of the participants, enable a professional to manage the project and clearly communicate their proposal. "This would have made a huge difference in our experience of the project."

On the contrary, carbon reductions (Table 2) came in at No 4, thus proving that the end user LED benefits ranked highly in the stakeholder project aims. Only the CEO and HoS thought about the carbon reduction impact of the scheme. Significantly, the results were not as strong as supporting the concept that LEDs presented tangible benefits as an attraction to the organisation, a position presented by Pye (2020). Thus, the focus group findings subsequently scored tangible benefits No 6 on the scale of importance. Lifecycle cost impacts and reduction of maintenance burden themes ranked 7 because they are only important to the CS, not the teaching staff and the school leadership on the focus group panel (details provided in Table 2).

Table 2 - Coding frequency responses from each of the participant on key retrofit issues

\begin{tabular}{|c|c|c|c|c|c|c|c|c|c|}
\hline Category or theme & $\begin{array}{l}\text { Tally } \\
\text { frequency }\end{array}$ & Position & $\begin{array}{l}\text { Category or theme: } \\
\text { Frequency per } \\
\text { person }\end{array}$ & CEO & DoF & $\mathrm{DoO}$ & $\mathrm{SP}$ & HoS & CS \\
\hline $\begin{array}{ll}\text { Carbon } & \text { Reduction } \\
(\mathrm{CR}) & \end{array}$ & 5 & 4 & $\begin{array}{l}\text { Carbon } \quad \text { Reduction } \\
(\mathrm{CR})\end{array}$ & 2 & 1 & 0 & 0 & 2 & 0 \\
\hline Tangible (TA) & 3 & 6 & Tangible (TA) & 1 & 1 & 0 & 0 & 0 & 1 \\
\hline Intangible (INT) & 9 & 2 & Intangible (INT) & 1 & 0 & 3 & 1 & 4 & 0 \\
\hline $\begin{array}{l}\text { Lack of Experience } \\
\text { (LOE) }\end{array}$ & 23 & 1 & $\begin{array}{l}\text { Lack of Experience } \\
\text { (LOE) }\end{array}$ & 5 & 4 & 3 & 4 & 6 & 1 \\
\hline Increased cost (IC) & 5 & 4 & Increased cost (IC) & 1 & 0 & 0 & 0 & 2 & 2 \\
\hline Lifecycle (LC) & 1 & 7 & Lifecycle (LC) & 0 & 0 & 0 & 0 & 0 & 1 \\
\hline $\begin{array}{l}\text { Reduce Maintenance } \\
\text { Burden (RMB) }\end{array}$ & 1 & 7 & $\begin{array}{l}\text { Reduce Maintenance } \\
\text { Burden (RMB) }\end{array}$ & 0 & 0 & 0 & 0 & 0 & 1 \\
\hline $\begin{array}{l}\text { End User Negative } \\
(\text { EUN) }\end{array}$ & 4 & 5 & $\begin{array}{l}\text { End user Negative } \\
(\text { EUN) }\end{array}$ & 0 & 1 & 0 & 2 & 1 & 0 \\
\hline
\end{tabular}




\begin{tabular}{|l|c|c|l|l|l|l|l|l|l|}
\hline Trust (TRU) & $\mathbf{7}$ & $\mathbf{3}$ & Trust (TRU) & $\mathbf{0}$ & $\mathbf{1}$ & $\mathbf{0}$ & $\mathbf{3}$ & $\mathbf{3}$ & $\mathbf{0}$ \\
\hline Rely on others (ROO) & $\mathbf{3}$ & $\mathbf{6}$ & Rely on others (ROO) & $\mathbf{2}$ & $\mathbf{0}$ & $\mathbf{0}$ & $\mathbf{0}$ & $\mathbf{1}$ & $\mathbf{0}$ \\
\hline
\end{tabular}

The benefits of LED lighting in a wider context of the school environment were captured in the focus group exercise. The DoF thinks that "an advantage of SALIX is that it is interest free". Also, "as a Trust, beginning in 2019 and 2020, we need to publish data on our carbon footprint, e.g. how many tonnes per pupil we generate." LED lights should, therefore, reduce our carbon footprint. CS sees benefits in terms of energy savings, environmental preservation, and lower maintenance costs. "Everything is covered in terms of energy and the environment, but also, LED lights last longer, and there is a time factor saved due to maintenance being less". SP summarises the feedback from the staff. "Generally it is a sense of a brighter and more positive learning environment. A negative is around the intensity of the lighting and sometimes we would like to turn off one of the 4 lights and the wiring does not allow this. This applies in the classroom, particularly if pupils are looking at screens". The incorporation of a dimmer switch would have solved this problem.

\section{LED versus florescent fittings}

The effectiveness of $L E D$ - savings in cost

The project pre-plan study of IGP in 2018, which was a prerequisite for the SALIX scheme of 1406 new LED luminaries, revealed that there could be an annual wattage usage reduction of $44 \%$ on fluorescent fittings, using Ansell manufactured LED luminaires. Poor quality LED fittings are proven not to deliver better efficacy due to a greater wattage draw. This supports Josijevićs (2017) and Kaip's (2017) positions. The secondary data from 2018, 2019 and 2020 used for this section was obtained from Zenergi, who are experienced in energy consultancy within education (Zenergi, 2020). The data is used to analyse the financial investment /tangible savings on school energy bills before and after the LED retrofit. 
Therefore, to achieve the best accuracy, the following months were considered 'normal' energy activity. Energy cost for the school over the 4 [Normal] months; September, October, November and December from 2018 to 2020. It is worth noting, pre-LED in 2017, the cost of electricity to the school was $£ 30,180.30 p$ over the same period. However, an average saving of $3500 \mathrm{kWh}$ was observed in 2017 (Zenergi, 2020). The increase in 2019 is partly due to major renovation work at the school as well as high day and night tariffs. As shown in table 3, 2017, was the base year with a $\mathbf{£ 3 0 , 1 8 0 ~ e n e r g y ~ c o s t , ~ w i t h ~ a ~ t a r i f f ~ o f ~} 11.095$ during the day and 7.024 pence at the night. The increment for the energy cost for the four months post retrofits as in table 3 is:

- $\quad$ Sept-Dec $\underline{2018}=\mathbf{£ 3 2 , 8 5 1}$ (Post LED year 1)

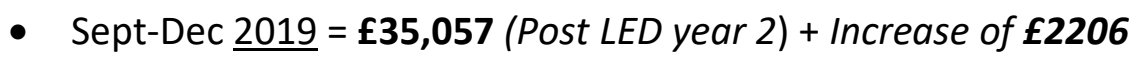

- Sept-Dec $\underline{2020}=\mathbf{£ 3 3 , 8 4 4}$ (Post LED year 3) - Decrease of $₫ 1213$

From 2017, the p/kWh during the daytime increased yearly by $8.88 \%$ in $2018,23 \%$ in 2019 and $2.20 \%$ in 2020. The night tariff increased by $10.44 \%$ in 2018, 61\% in 2019 and $2.87 \%$ in 2020. The increase in tariffs makes repayment of SALIX funding from the savings made from electricity bills impossible.

Table 3 Electricity yearly actual price and the increment in the tariff

\begin{tabular}{|c|c|c|c|c|c|c|c|}
\hline \multicolumn{2}{|c|}{2017} & \multicolumn{2}{c|}{2018} & \multicolumn{2}{c|}{2019} & \multicolumn{2}{c|}{2020} \\
\hline $\begin{array}{c}2017 \text { as } \\
\text { charges/tariff } \\
\text { fees }\end{array}$ & $\begin{array}{c}2017 \\
\text { actual } \\
\text { price }\end{array}$ & $\begin{array}{c}2018 \text { as } \\
\text { charges/tariff } \\
\text { fees }\end{array}$ & $\begin{array}{c}2018 \\
\text { actual } \\
\text { price }\end{array}$ & $\begin{array}{c}2019 \\
\text { charges/tariff } \\
\text { fees }\end{array}$ & $\begin{array}{c}2019 \\
\text { actual } \\
\text { price }\end{array}$ & $\begin{array}{c}\text { 2020 } \\
\text { charges/tariff } \\
\text { fees }\end{array}$ & $\begin{array}{c}2020 \\
\text { actual price }\end{array}$ \\
\hline $\begin{array}{l}\text { 11.095 Day } \\
\text { 7.024 Night }\end{array}$ & $\pm 30,180$ & $\begin{array}{c}12.0797 \text { Day } \\
7.7574 ~ N i g h t\end{array}$ & $f 32,851$ & $\begin{array}{c}14.8764 \text { Day } \\
12.4897 \text { Night }\end{array}$ & f35,057 & 15.2046 Day & f33,844 \\
\hline
\end{tabular}


These findings are contrary to the promise of up to $45 \%$ savings on energy bills through LEDs as suggested by Pye (2020). It is also worth noting that Pye's (2020) recent focus was on the commercial setting. The secondary financial data in Table 4 presented difficulties in accuracy due to the fact that the energy prices are irregular, sporadic spikes and prices are dependent on wider issues outside of the school's control in some periods under review. For instance, the author observed sporadic spikes in energy prices during the period under review (Zenergi, 2020). The school also had internal factors, such as building works in August 2019, which demanded high electricity to improve other areas of the estate. Another recent example is a whole school closure due to the global pandemic in the spring of 2020. This is validated (Whole School) electricity monthly cost information before and after the LED retrofit [2018-2020]. This shows the marginal tangible savings influenced by energy prices.

Savings in Watts/kWh used after the LED Retrofit

Appleby (2013) argues that older buildings do not meet the modern standard of energy performance. Appleby (2013) suggests retrofitting is a package and should be considered in partnership with other sustainable technologies. Relating this theory to this project, only the light units were fitted. For example, no PIR $^{1}{ }^{S}\left[\right.$ Passive Infra-Red ${ }^{2}$ ] or modern switches were installed, which would have improved LED performance further. In this project, for example, even though many of the campus buildings range between the 1930s-1970s. Table 4 presents the comparison of 2018 projected (planned) usage in the IGP versus actual consumption through meter readings in 2020 for the 1406 luminaires for 9 buildings. The result shows a $25.6 \%$ annual savings in watts was projected, but $44 \%$ savings was achieved.

Table 4 - The comparison of the LED wattage savings, planned vs. actual consumption

\begin{tabular}{|c|c|}
\hline $\begin{array}{c}\text { Pre-project annual plan in IGP in } \\
2018\end{array}$ & Post-project annual consumption \\
2020
\end{tabular}

${ }^{1}$ PIRs sense movement and control lighting when rooms are unoccupied. 


\begin{tabular}{|c|c|c|c|}
\hline Total luminaires & 1406 & Total luminaires & 1406 \\
\hline Total building & 9 & Total building & 9 \\
\hline $\begin{array}{l}\text { Existing annual usage } \\
\text { (2018) }\end{array}$ & 205.770 watts & $\begin{array}{l}\text { New annual usage } \\
(2020)\end{array}$ & 90.712 watts \\
\hline $\begin{array}{l}\text { Projected Total Annual } \\
\text { wattage }\end{array}$ & 153.170 watts & $\begin{array}{l}\text { Consumption actual } \\
\text { savings/difference }\end{array}$ & 115.058 watts \\
\hline $\begin{array}{l}\text { Projected wattage } \\
\text { savings in } 2018\end{array}$ & 52.600 watts & & \\
\hline $\begin{array}{l}\% \text { annual projected } \\
\text { savings }\end{array}$ & $25.6 \%$ & $\%$ annual savings & $\begin{array}{l}44 \% \text { (actual } \\
\text { annual savings) }\end{array}$ \\
\hline
\end{tabular}

Table 5 shows that LEDs delivered an annual 2.68\% and 20\% reduction in KWh usage in 2019 and 2020 respectively to the school in relation to 2018 base consumption. The huge gap between 2019 and 2020 might be in part because of the impact of Covid 19. However, the trend from 2019 supports the wider theories surrounding LED efficiency and retrofitting LED into schools. It also supports the overall carbon reduction mission, as mandated by UK law. This is critical, as delivering new built environments for education is an impossibility before the 2050 zero carbon deadline. However, the success would have been greater had other technologies been installed to support the retrofitted lighting (Appleby, 2013).

Table 5 The Whole School KWh actual usage [2016-2020]

\begin{tabular}{|l|l|l|l|l|l|}
\hline Month & 2016 & $\mathbf{2 0 1 7}$ & $\mathbf{2 0 1 8}$ & $\mathbf{2 0 1 9}$ & $\mathbf{2 0 2 0}$ \\
\hline Jan & & 75868.1 & 73792.8 & 68280.1 & 70874 \\
\hline Feb & & 63664.8 & 64230.9 & 57363.3 & 64811.3 \\
\hline Mar & & 73408 & 74420.5 & 52298.3 & 60040.9 \\
\hline Apr & & 47084 & 53458.3 & 51224.1 & 31057.3 \\
\hline May & & 58752.1 & 61144.8 & 55845.6 & 29167.8 \\
\hline
\end{tabular}




\begin{tabular}{|c|c|c|c|c|c|c|}
\hline \multirow{8}{*}{ LEDs } & Jun & & 55052.7 & 57581.7 & 55318 & 27569.1 \\
\hline & Jul & 56031.9 & 50437.6 & 58013.4 & 54800.7 & 30229.5 \\
\hline & Aug & 37621.2 & 34820.5 & 29145.3 & 38285.3 & 28811.3 \\
\hline & Sep & 62287.3 & 57809.1 & 58485.9 & 58479.6 & 49373.2 \\
\hline & Oct & 63072.2 & 60599.6 & 62597.9 & 65940.2 & 55983.2 \\
\hline & Nov & 76268.8 & 72107 & 68835.4 & 69748.9 & 54747 \\
\hline & Dec & 61488.4 & 61561 & 56014.8 & 70899.3 & 59375.3 \\
\hline & Grand Total & 356769.8 & 711164.5 & 717721.7 & 698483.4 & 562039.9 \\
\hline
\end{tabular}

delivering carbon reduction

Using the SALIX (2017 and 2021) carbon project planning with the actual Co2 saving in table 6. The data was submitted to SALIX and validated by the energy providers. The findings show that in 2018, a 51.59 Co2 T reduction in carbon savings was forecasted after the LED retrofit. In 2020, the LED delivered a 10 Co2 T over achievement (saving). Overall, 61.3 Co2 T of carbon was saved. This finding aligns with the study by Dandan and Humphries (2016), which concludes that LEDs provide a substantial reduction in the overall carbon footprint of the organisation.

Table 6 pre and post project analysis (source SALIX, 2018)

\begin{tabular}{|c|c|c|c|c|c|}
\hline Year & $\begin{array}{c}\text { Annual Kwhrs } \\
\text { Pre project }\end{array}$ & $\begin{array}{c}\text { Annual Kwhrs } \\
\text { Post project }\end{array}$ & $\begin{array}{c}\text { Annual KWh } \\
\text { savings }\end{array}$ & $\begin{array}{c}\text { \% KWh } \\
\text { savings }\end{array}$ & tCo2 pa \\
\hline 2018 & 220,865 & 106,049 & 114,816 & $52 \%$ & 51.59 \\
\hline 2021 & 698,483 & 562,040 & 136,443 & $20 \%$ & 61.31 \\
\hline
\end{tabular}

\section{Consequences of LEDs retrofitted to the organisation}

The questionnaire results suggest the end-users of the LED retrofits are very satisfied. For example, $58 \%$ of staff noted a better learning environment for pupils, supporting the theory 
presented by Gentile et al (2017). Whereby, no negative effects were observed on pupil learning in the classroom environment fitted with LED lighting. $64.7 \%$ of staff suggested a decrease in lighting maintenance within the workplace (post retrofit). This supports the theory presented by Bento and Marques (2020), Kaip (2017) and the DBIS (2020), who clearly define LEDs as costeffective to maintain.

On the issue of poor night sleep, 76.4\% of employees disagreed that LED exposure resulted in a poor night's sleep after work. Thus, questioning the theory presented by Rongpeng et al., (2020), contesting the view that LED lights have a negative effect on the workplace. On the contrary, $68.3 \%$ of employee attitudes suggested that LEDs contributed to a better working environment. Significantly, the survey results demonstrated that $91.2 \%$ of staff would consider more LED lighting retrofitted into the school. This is indicative of the overall productivity of staff within the organisation. The findings support the view posed by IWFM (2020) that better facilities, which offer user comfort are vital to the efficiency of employees within the workplace. The results unanimously present an argument supporting the view that LED retrofitted lighting delivers a number of intangible benefits, thus presenting favourable consequences for the organisations who commission this type of sustainability project.

Overall, the participants' attitude was in support of the wider academic view that LEDs deliver carbon reductions, thus delivering environmental improvements. This perspective supports the statement by the UK energy watch (2020). The counterproductive theories surrounding LEDs posed by Divine (2016) and Josijević (2017) are not supported by the survey results. Two questions in the survey were considered inconclusive by the author. The optical comfort of LED and learning within a presentational environment would need further investigation to understand the effect of LED within this specific area. Complicated contracts, with drawn out negotiations, nullify successful projects. This study discovered $35 \%$ of stakeholders viewed government policy as the main driver for entering into finance. With $28 \%$ of stakeholders entering schemes, though, there is a sheer lack of available capital.

\section{STUDY IMPLICATION AND PRACTICAL CONTRIBUTION}


As the UK's 2050 target for zero carbon approaches, educational leaders are continuously seeking improvements to their organisation's carbon footprint. This paper will help school senior professionals think holistically about LED retrofit projects. Although the carbon saving may seem attractive, the loan scheme options offered by SALIX may not be fully understood to deliver the project intent. Therefore, senior leadership may consider adding to the stakeholder cohort with more engineering and design expertise to ensure the project journey from conception to end of life is fully realised. LED lighting in the classroom also has many benefits, generally brighter, attractive and modernised school spaces which are positively received by the staff and enhances education and sustainability through carbon reduction. This is having beneficial outcomes for schools beyond facility and building improvements. Away from education, this paper offers the governmental organisations that support school energy projects and finance providers an insight into the challenges of LED retrofit. Generating debate to support a future joined-up approach to how schemes are delivered. Currently, the Public Sector Decarbonisation Scheme (PSDS) is looking at best practice criteria, funding and delivery. LED retrofit in the education sector will play a key role in future policy and practice. Calculating the complexity of energy efficiency and performance is a major hurdle within older buildings. Future research opportunities surround the combination of a plethora of energy saving initiatives exist. For example, the LED lighting relationship with building thermodynamics plays a key role in energy savings and is rarely discussed together.

\section{CONCLUSIONS}

While the wider academic and engineering theory presents a variety of viewpoints on LED technology, this research was aimed at determining the amount of savings in cost, carbon reduction, and kilowatt usage in LED retrofit school projects funded through the SALIX funding option in the UK and confirming if repayment from energy and cost savings derived from those retrofits would be sufficient to service the SALIX loan. Accordingly, it examined monetary and non-monetary benefits, internal project stakeholder knowledge gaps, and the consequences of LED retrofit for the staff and enablers of schools funded through the SALIX funding option in the UK. In addition to a comprehensive review of literature, a rigorous analysis and validation of a single case study of a large, Community Secondary School in the UK were carried out which were 
executed based upon the data collected through a focus group, a questionnaire survey and other secondary sources in the case study. Although the study is limited to the UK, the same design methodology can be used to assess the benefits of local retrofit schemes.

Government finance options are attractive opportunities for senior school stakeholders, who face a number of pressures, including fast paced innovation, repayment modalities, and lack of knowledge about the SALIX scheme. The qualitative research results revealed a lack of experience by the group within the school LED project team. The evidence also presented a lack of trust in the contractors, who were seen as attempting to dilute outcomes. For example, project briefs are overindulged with expert data, consuming stakeholders born out of the teaching profession who are not experts in the field. Some of the knowledge deficiencies identified are in the areas of commercialisation of the scheme, financial costs, daunting project scale, service level agreement with the LA currently for the loan baseline information, lack of understanding of LED technology, management of the lights and management of risks.

On the effectiveness and tangible benefits of LEDs, it was revealed that the paybacks on bills are difficult to estimate due to a fluctuating energy market. This resulted in an unaccounted need to use organic school capital from the GAG to meet the payments. This proves that contractors do not paint a clear picture of risk in the brief. This is combined with the lack of experience (LOE) of stakeholders. The money promised for energy savings had a negative impact on the school's capital forecast. This is due to the sporadic nature of the energy market, which makes it impossible to analyse the impacts at the project conception stage. Even if savings were made, it would be difficult to reflect on the bills because of the increase in energy prices. Since the payback is tied to GAG, it will be difficult to see the savings in real time. The government therefore, should adjust the payback modalities to the base price of tariffs as of when the SALIX loan was granted and the IGP prepared, so that repayment should not affect the GAG.

The LED performance in reducing kWh and carbon usage was remarkable. LEDs retrofitted overachieved in this area. It supports the debate that LEDs are changing the way buildings are illuminated. The findings cement the view that LEDs deliver 'sustainably' performance to the organisation. This also contributes to the limited research into sustainability projects within schools. Some real, intangible benefits of an LED retrofit to school enablers include 
improvements in the indoors of the school environment. Staff were supportive of LED. Evidence revealed no optical or user comfort issues, which challenged some academic theories presented in the literature review. However, it is worth noting a research gap still exists regarding larger group learning, for example, effective lighting in group learning/presentations. This area proved inconclusive, presenting a further research opportunity.

\section{REFERENCES}

Adu, P. (2019) Qualitative Analysis: Coding and Categorising [Online Video], 17 December 2016. Available from https://youtu.be/v_mg7OBpb2Y, visited 10 June 2021

Ahn, Y. N., Kim, K.D., Kim, G.S. and Ypp, J.S. (2019) Design of highly efficient phosphor-converted white light-emitting diodes with color rendering indices (R1-R15) $\geq 95$ for artificial lighting. Sci Rep 9, 16848 [Online] Available from: <https://doi.org/10.1038/s41598-01953269-0>

Alexander, K. (2016) Facilities management. Theory and practice [Online]. London: Routledge.

Appleby, P. (2013) Sustainable retrofit and facilities management [Online]. London: Routledge.

Badi, S. (2017) Public sustainable-energy requirements and innovation in UK PFI school projects. Construction Management \& Economics, 35(4), p. 218-238.

Batra, S. Pandav, S. and Ahuja, S. (2019) Light Emitting Diode Lighting Flicker, its Impact on Health, and the Need to Minimise it. Journal of Clinical \& Diagnostic Research [Online], 13(5), p. 1-5.

Bento, F. and Marques Cardoso, A. (2020) Fault-Tolerant LED Lighting Systems Featuring Minimal Loss of Luminous Flux. IEEE Transactions on Industry Applications [Online], 56(4), p. 43094318.

Braham, W. and Willis, D. (2013) Architecture and energy, performance and style [Online]. London: Routledge.

Carey, M. and Asbury, J. (2012) Focus group research. Qualitative essentials [Online] California: Left Coast Press.

Carrillo, P. Robinson. H. Foale, P. Anumba, C. and Bouchlaghem, D. (2008) Participation, Barriers, and Opportunities in PFI: The United Kingdom Experience. Journal of Management in Engineering [Online], 24(3), p. 138-145.

Chinchero, F. Alonso, M. and Ortiz T. (2020) LED lighting systems for smart buildings: a review. IET smart cities [Online], (3), p. 126-134.

Dadzie, J., Runeson, G. and Ding, G. (2020), "Assessing determinants of sustainable upgrade of existing buildings: The case of sustainable technologies for energy efficiency", Journal of 
Engineering, Design and Technology, Vol. 18 No. 1, pp. 270292. https://doi.org/10.1108/JEDT-09-2018-0148

Dandan, Z. and Humphreys, C. (2016) Solid-State Lighting Based on Light Emitting Diode Technology, Optics in Our Time [Online], p. 87-98.

Divine, T. (2016) Is an LED right for your next retrofit project? Consulting Specifying Engineer [Online], 53(7), p. 40.

Dunn, R. Krimsky, J. Murray, J. and Quinn, P. (1985) Light up Their Lives, the Reading Teacher, 38(9), 863-869. [Online] Available from: <http://www.jstor.org/stable/20198961>

Dupuis, P. Barroso, A. Canale, L. Alonso, C. and Zissis, G. (2014) LED lighting - Reduce the power consumption and increase the user's comfort. 2014 IEEE Industry Application Society Annual Meeting [Online], 2014 IEEE, pp. 1-5.

Fasna, M.F.F. and Gunatilake, S. (2020) Roles and functions of stakeholders in implementing energy retrofits in the hotel sector", International Journal of Building Pathology and Adaptation, Vol. 38 No. 5, pp. 737-751. https://doi.org/10.1108/IJBPA-10-2019-0088

Hennink, M. (2014) Focus group discussions. Understanding qualitative research [Online]. New York: Oxford University Press.

Higgin, G. and Jessop, N. (1965) Communications in the building industry: the report of a pilot study [Online]. London: Tavistock Publications.

Institute of Workplace and Facilities Management [IWFM] (2020) What is workplace and facilities management? [Online] Bishops Stortford. Available from: <https://www.iwfm.org.uk/about/what-is-workplace-and-facilities-management.html\# >

Johnston, M. (2017) Secondary Data Analysis: A Method of which the Time Has Come, Qualitative and Quantitative Methods in Libraries [Online], v. 3, n. 3, p. 619-626.

Josijević, M. Gordić, R. Milovanović, M. Jurišević, M. and Rakić, Ž. (2017) A method to estimate savings of led lighting installation in public buildings: The case study of secondary schools in Serbia, Thermal Science [Online], 21(6 Part B), pp. 2931-2943.

Kaip, J. (2017) Quantifying the Carbon Reduction Impact of a University LED Lighting Retrofit Program [Ph.D. thesis]. Miami University.

Kulkarni, S., Chapman, C., Shah, H., Parn, E.A. and Edwards, D.J. (2018), "Designing an efficient tidal turbine blade through bio-mimicry: a systematic review", Journal of Engineering, Design and Technology, Vol. 16 No. 1, pp. 101-124. https://doi.org/10.1108/JEDT-08-2017-0077

Lawson, B., Statsenko, L. and Shokri-Ghasabeh, M. (2021), "Value co-creation in asset integrity and improvement portfolio: evidence from the Australian mining industry", Journal of Engineering, Design and Technology, Vol. ahead-of-print No. ahead-ofprint. https://doi.org/10.1108/JEDT-04-2021-0230 
Lenk, R. and Lenk, C. (2011) Practical lighting design with LEDs. [Online] Chichester: Wiley-IEEE Press (IEEE Press series on power engineering: 67)

Lofland, J. and Lofland, L. H. (1995). Analysing social settings: a guide to qualitative observation and analysis. Belmont: Wadsworth.

Marketwatch (2021) Global LED Retrofit Sales Market Size 2021https://www.marketwatch.com/press-release/global-led-retrofit-sales-market-size2021-analysis-by-emerging-trends-industry-share-top-impacting-factors-key-manufacturesapplications-and-forecasts-up-to-2027-2021-04-27, visited April 2021

McLeod, S. (2019) Likert Scale Definition, Examples and Analysis. [Online] Available from: < https://www.simplypsychology.org/likert-scale.html >, visited September 2020

Mills, E. and Jacobson, A. (2011) From carbon to light: a new framework for estimating greenhouse gas emissions reductions from replacing fuel-based lighting with LED systems. Energy Efficiency [Online], 4(4), p. 523.

Oyegoke, A.S. (2005), Infrastructure Project Finance and Execution Development

Strategies, Journal of The Nigerian Institute of Quantity Surveyors, Vol.52 (3), pages: 11-19

Pye, A. (2020) Acting smart with industrial lighting: The big news over the past few years in lighting circles has been the move to LED lighting for energy reasons. Plant \& Works Engineering [Online], p. 36.

Raditschova, J. and Gasparovsky, D. (2018) Critical Analysis of Cost Benefits of LED Retrofits in Indoor Lighting. 2018 VII. Lighting Conference of the Visegrad Countries (Lumen V4). Hungry: Lumen.

Rongpeng, Z. Campanlle, C. Aristizbal, S. Jamrozik, A. Zhao, J. Porter, P. Ly, S. and Bauer, B. (2020) Impacts of Dynamic LED Lighting on the Well-Being and Experience of Office Occupants. International Journal of Environmental Research and Public Health.

Roy, S., Majumder, S., Bhattacharya, S. and Sardar, I.H. (2021), "Simulation and analysis of the effects of room surface reflectance combinations on a proposed retrofit illumination system of an office", Journal of Engineering, Design and Technology, Vol. ahead-of-print No. aheadof-print. https://doi.org/10.1108/JEDT-10-2020-0400

Saldaña, J. (2013). The coding manual for qualitative researchers. Los Angeles: SAGE Publications.

Salem, R. Bahadori-Jahromi, A. Mylona, A. Godfrey, P. and Cook, D. (2019) Investigating the potential impact of energy-efficient measures for retrofitting existing UK hotels to reach the nearly zero energy building (nZEB) standard, Energy Efficiency [Online], vol. 12, no. 6, p. 1577.

SALIX (2017) CIF and SEEF energy saving support tool -Version 3. London: SALIX Finance Ltd.

Saunders, M. Lewis, P. and Thornhill, A. (2007). Research Methods for Business Students, (6th edition). London: Pearson. 
Stravoravdis, S. (2013) 'Lighting offices with LEDs: a study on retrofitting solutions' [Ph.D. thesis]. Cardiff University.

The Climate Group (2020) LED scale up. [Online] London: Available from: < https://www.theclimategroup.org/project/led-scale> visited March 2021

The Department for Business and Industrial Strategy (2020) Energy Technology List. Lighting. A guide to energy efficient equipment that is eligible for The Energy Technology List [Online] London: 2020.

The Department for Business, Energy \& Industrial Strategy (2019) UK becomes first major economy to pass net zero emissions law. Available from: < https://www.gov.uk/government/news/ukbecomes-first-major-economy-to-pass-net-zero-emissions-law > visited December 2020

The Department of Education (2020) Our Energy Use [Online] London: Gov.uk Available from: < https://www.gov.uk/government/organisations/department-for-education/about/ourenergy-use\#real-time-data-about-energy-use> visited January 2021

The Interactive Biodiversity Information Systems Limited (2020) LED lighting retailing in the UK. [Online] Los Angeles: IBIS World. Available from :< https://www.ibisworld.com/unitedkingdom/market-research-reports/led-lighting-retailing-industry/ > visited August 2020

The UK Energy Watch (2020) School LED Lighting. [Online] Lytham St Anne's: Available from: < https://ukenergywatch.co.uk/sectors/schools/school-led-lighting/ > visited August 2020

The University of St Andrews (2020) Analysing Likert Sale data [PDF] Available from: <https://www.st-andrews.ac.uk/media/ceed/students/mathssupport/Likert.pdf > visited August 2020

Woźniak, W. (2014) Homogeneity of Focus Groups as a Pathway to Successful Research Findings? Przegląd Socjologii Jakościowej / Qualitative Sociology Review [Online], X (1), pp. 623.

Zenergi (2020) Positive Energy Pack, Sawston Village College. [Excel], Southampton: Hampshire. 